\title{
Dok. 2 \\ Konkluzje Rady Europejskiej z posiedzenia, 28/29 czerwca 2012 r.
}

Załącznik

\section{PAKT NA RZECZ WZROSTU GOSPODARCZEGO I ZATRUDNIENIA}

Szefowie państw lub rządów,

wyrażając swoją determinację, by w kontekście strategii „Europa 2020" stymulować inteligentny, trwały i zasobooszczędny wzrost gospodarczy sprzyjający tworzeniu miejsc pracy i włączeniu społecznemu,

podkreślając potrzebę mobilizowania w tym celu, na każdym szczeblu zarządzania w Unii Europejskiej, wszystkich środków działania, narzędzi i polityk, przypominając o tym, jak duże znaczenie dla trwałego wzrostu gospodarczego mają zdrowe finanse publiczne, reformy strukturalne i ukierunkowane inwestycje, podejmują decyzję w sprawie następującego paktu:

\section{Działania, jakie należy podjąć na poziomie państw czlonkowskich}

1) Wszystkie państwa członkowskie nadal wyrażają zdecydowaną wolę natychmiastowego podejmowania na poziomie krajowym działań niezbędnych do realizacji celów strategii „Europa 2020”. Nowe narzędzia Unii Europejskiej w zakresie zarządzania gospodarczego muszą być stosowane skutecznie i w pełnym wymiarze, a wzajemna presja musi zostać zwiększona. Należy szybko przyjąć omawiane jeszcze wnioski mające na celu zakończenie tworzenia tych ram („dwupak”).

2) Podczas realizacji zaleceń dla poszczególnych krajów państwa członkowskie położą szczególny nacisk na następujące aspekty:

a) dalsze prowadzenie zróżnicowanej i sprzviaiacei wzrostowi gospodarczemu konsolidacii fiskalnei, z poszanowaniem paktu stabilności i wzrostu oraz z uwzględnieniem specyfiki poszczególnych państw: szczególną uwagę należy poświęcić kierowaniu inwestycji na obszary o dużym znaczeniu dla przyszłości i bezpośrednio związane z potencjałem wzrostu gospodarczego oraz zapewnianiu stabilności systemów emerytalnych. Komisja monitoruje wpływ dużych ograniczeń budżetowych na wydatki publiczne zwiększające wzrost gospodarczy oraz na inwestycje publiczne. Przedstawi sprawozdanie na temat jakości wydatków publicznych oraz możliwości działania w obrębie unijnych i krajowych ram fiskalnych:

b) przywracanie normalnego poziomu kredytowania gospodarki i pilne dokończenie restrukturyzacji sektora bankowego:

c) propagowanie wzrostu gospodarczego i konkurencviności, w szczególności poprzez usuwanie głęboko zakorzenionych zakłóceń równowagi i kontynuowanie 
reform strukturalnych, aby uwolnić krajowy potencjał wzrostu gospodarczego, w tym poprzez otwarcie sektorów sieciowych na konkurencję, upowszechnianie gospodarki cyfrowej, wykorzystywanie potencjału zielonej gospodarki, usuwanie nieuzasadnionych ograniczeń dotyczących usługodawców oraz ułatwianie rozpoczynania działalności gospodarczej;

d) skuteczne radzenie sobie $\mathrm{z}$ bezrobociem i ze społecznymi konsekwenciami kryzysu; realizacja reform służących zwiększeniu zatrudnienia; nasilanie wysiłków na rzecz zwiększania zatrudnienia młodych ludzi - w szczególności aby poprawić możliwości zdobywania przez nich pierwszych doświadczeń zawodowych i zwiększyć ich udział w rynku pracy - przy dążeniu do tego, by w ciagu kilku miesięcy od zakończenia nauki młodzi ludzie otrzymywali dobrej jakości ofertę zatrudnienia, dalszego kształcenia, przyuczania do zawodu lub praktyk zawodowych, co może być wspierane ze środków EFS; oraz opracowywanie i realizowanie skutecznych polityk służących zwalczaniu ubóstwa i wspieraniu słabszych grup społecznych. Państwa członkowskie szybko wdrożą swoje krajowe plany zwiększania zatrudnienia i przygotują ambitniejsze i precyzyjniejsze krajowe plany zwiększania zatrudnienia na kolejny europejski semestr. Państwa członkowskie powinny wykorzystywać możliwości, jakie w zakresie finansowania dotacji na tymczasowe zatrudnianie oferuje Europejski Fundusz Społeczny;

e) modernizacja administracji publicznei, w szczególności poprzez eliminowanie opóźnień w sądownictwie, zmniejszanie obciążeń administracyjnych i rozwijanie usług administracji elektronicznej. Należy prowadzić wymianę najlepszych praktyk w tym zakresie.

\section{Wkład polityk europejskich we wzrost gospodarezy i zatrudnienie}

3) Na poziomie Unii Europejskiej konieczne są dalsze pilne środki, by zwiększyć wzrost gospodarczy i zatrudnienie oraz poprawić finansowanie gospodarki w krótkiej i średniej perspektywie, a także zwiększyć konkurencyjność Europy jako docelowego miejsca produkcji i inwestycji.

a) Pogłębienie jednolitego rynku poprzez usunięcie wciąż istniejących barier będzie jednym z kluczowych czynników we wspieraniu wzrostu gospodarczego i zwiększaniu zatrudnienia, w szczególności w sektorach cyfrowych i sieciowych. W tym celu na jesieni 2012 roku Komisja zamierza przedstawić dalsze sprzyjające wzrostowi środki jako część drugiego Aktu o jednolitym rynku. Poczyniono już istotne postępy odnośnie do środków, które są częścią pierwszego Aktu o jednolitym rynku; chodzi m.in. o: przyjęcie wniosku w sprawie normalizacji i porozumienie wypracowane przez Radę co do wniosku w sprawie rachunkowości, wniosku w sprawie funduszy kapitału wysokiego ryzyka i wniosku w sprawie funduszy na rzecz przedsiębiorczości społecznej, a także co do wniosku w sprawie alternatywnego rozstrzygania sporów i wniosku w sprawie internetowego rozstrzygania sporów. Jak najszybciej należy osiągnąć porozumienie w zakresie wniosków w sprawie zamówień publicznych, podpisu elektronicznego oraz uznawania kwalifikacji zawodowych. $Z$ aprobatą przyjęto komunikat Komisji w sprawie usprawnienia zarządzania jednolitym rynkiem. Państwa członkowskie 
i Komisja zapewnią lepszą realizację i egzekwowanie przepisów dotyczących jednolitego rynku, a Komisja będzie monitorować wyniki, w tym w ramach rocznego sprawozdania sporządzanego w ramach europejskiego semestru. Z zadowoleniem przyjęto także komunikat Komisji w sprawie wdrażania dyrektywy usługowej; należy natychmiast podjąc działania wdrażające, w tym poprzez rygorystyczna wzajemną ocenę krajowych ograniczeń i szybkie działania na rzecz usunięcia nieuzasadnionych barier. Dyrektywa ta umożliwia osiagnięcie dodatkowych zysków ekonomicznych, nawet do wysokości 330 mld EUR. Do końca 2012 roku Rada Europejska dokona przeglądu poczynionych postępów.

b) Konieczne są szybkie postępy na drodze do utworzenia do 2015 roku dobrze funkcjonujacego jednolitego rynku internetowego, który da europejskiej gospodarce nowy impuls. W szczególności priorytetowo należy traktować środki mające na celu dalsze rozwijanie transgranicznego handlu elektronicznego, w tym poprzez ułatwianie przejścia do fakturowania elektronicznego, oraz promowanie transgranicznego stosowania elektronicznej identyfikacji oraz innych usług elektronicznych. Kluczowe znaczenie ma także zwiększanie popytu na upowszechnianie szybkiego Internetu, modernizowanie europejskiego systemu prawa autorskiego oraz ułatwianie uzyskiwania licencji, przy jednoczesnym zapewnieniu wysokiego poziomu ochrony praw własności intelektualnej oraz uwzględnieniu różnorodności kulturowej.

c) Konieczne są dalsze wysiłki na rzecz zmniejszania ogólnych obciażeń regulacvinvch na poziomie UE i na poziomie krajowym. Przed końcem 2012 roku Komisja przedstawi komunikat dotyczący dalszych działań w zakresie inteligentnych regulacji, w tym środków wspierania mikroprzedsiębiorstw.

d) Pełna realizacja wewnętrznego rynku energii do 2014 roku w myśl uzgodnionych terminów i dopilnowanie, by po 2015 roku żadne państwo członkowskie nie pozostało poza europejskimi sieciami gazowymi i elektrycznymi, znacznie przyczyni się do zwiększenia unijnej konkurencyjności, wzrostu gospodarczego i zatrudnienia. Po formalnym przyjęciu dyrektywy o efektywności energetycznej państwa członkowskie będą musiały szybko ją wdrożyć, w pełni wykorzystując jej przepisy do uwolnienia znacznego potencjału w zakresie tworzenia miejsc pracy w tym sektorze. Należy szybko osiągnąc porozumienie w sprawie wniosku dotyczącego transeuropejskiej infrastruktury energetycznej.

e) Konieczne są dalsze działania służące temu, by wysiłki w sektorze badań szybko przekładały się na innowacie wychodzące naprzeciw potrzebom rynku i w ten sposób wzmacniały konkurencyjność Europy i pomagały radzić sobie z wyzwaniami społecznymi. Należy wzmocnić europejską przestrzeń badawczą, w szczególności poprzez zwiększanie wsparcia dla badań i rozwoju oraz możliwości inwestowania przez innowacyjne nowe przedsiębiorstwa i MŚP. Przyszły program na rzecz konkurencyjności przedsiębiorstw i MŚP (COSME) i program „Horyzont 2020" pomogą innowacyjnym MŚP uzyskać dostęp do finansowania. Szczególne znaczenie ma wzmocnienie kluczowych technologii wspomagających mających znaczenie systemowe dla innowacyjności i konkurencyjności przemyshu i całej gospodarki, w tym w takich obszarach jak nanotechnologia, biotechnologia i materialy zaawansowane. 
f) W przypadku niektórych krajów zreformowana polityka spóiności daje możliwość wyjścia z kryzysu przez inwestycje, ponieważ jest ona ważnym narzędziem służącym inwestowaniu, wzrostowi gospodarczemu i tworzeniu miejsc pracy na szczeblu UE, a także reformom strukturalnym na szczeblu krajowym. Odpowiada za istotną część inwestycji publicznych w UE i przyczynia się do pogłębienia rynku wewnętrznego.

g) Wypracowane dzisiaj porozumienie w sprawie jednolitego systemu ochrony patentowej zaowocuje znacznym obniżeniem kosztów, jakie ponoszą MŚP, i będzie bodźcem do innowacji, gdyż zapewni Europie przystępny, wysokiej jakości patent z jednolitą wyspecjalizowana jurysdykcją.

h) Bardzo istotne znaczenie ma pobudzenie finansowania gospodarki. Kwota 120 mld EUR (czyli ok. 1\% DNB UE) jest uruchamiana na szybko działające środki na rzecz wzrostu gospodarczego:

- Kapitał wpłacony EBI powinien zostać zwiększony o 10 mld EUR w celu wzmocnienia podstawy kapitałowej tego banku oraz zwiększenia jego całkowitej zdolności udzielania pożyczek o $60 \mathrm{mld}$ EUR, co uwolni do $180 \mathrm{mld}$ EUR na dodatkowe inwestycje w całej Unii Europejskiej, w tym w państwach najbardziej podatnych na zagrożenia. Decyzja powinna zostać podjęta przez Radę Gubernatorów EBI, tak by mogła wejść w życie nie później niż 31 grudnia $2012 \mathrm{r}$.

- Należy natychmiast rozpocząć fazę pilotażową obligacji projektowych, które przyniosą dodatkowe środki w wysokości do 4,5 mld EUR na inwestycje w pilotażowe projekty w obszarach kluczowej infrastruktury transportowej, energetycznej i szerokopasmowej. Jeżeli sprawozdanie okresowe i ocena fazy pilotażowej będą pozytywne, w przyszłości we wszystkich krajach można będzie jeszcze zwiększyć wolumen takich instrumentów finansowych, w tym na rzecz instrumentu „Łącząc Europę”.

- W stosownych przypadkach - i przy poszanowaniu zasad umarzania - państwa członkowskie maja, na mocy obowiązujących przepisów i istniejących praktyk, możliwość współpracy z Komisja, by wykorzystać część przyznanych im w ramach funduszy strukturalnych środków na udział w ryzyku kredytowym EBI i zapewnienie gwarancji kredytowych w zakresie wiedzy i umiejętności, efektywnego gospodarowania zasobami, infrastruktury strategicznej oraz w zakresie dostępu do finansowania dla MŚP. W ramach funduszy strukturalnych realokowano środki, wykorzystując je na wsparcie badań i innowacji, MŚP oraz zatrudnienie młodzieży, a dalszych 55 mld EUR zostanie w obecnym okresie przeznaczonych na środki sprzyjające wzrostowi gospodarczemu. Należy jeszcze bardziej zwiększyć wsparcie dla MŚP, w tym przez zapewnienie im łatwiejszego dostępu do unijnych środków finansowych. Państwa członkowskie mają także możliwość rozważenia realokacji w obrębie swoich krajowych pul środków finansowych, w ramach obowiązujących przepisów i we współpracy z Komisją.

- Należy także zintensyfikować działania Europejskiego Funduszu Inwestycyjnego, w szczególności w zakresie kapitału wysokiego ryzyka, w powiązaniu $\mathrm{z}$ istniejącymi strukturami krajowymi. 
i) Budżet Unii Europejskiej musi być katalizatorem wzrostu gospodarczego i zatrudnienia w Europie, w szczególności poprzez lewarowanie produktywnych inwestycji i inwestycji w kapitał ludzki. W przyszłych wieloletnich ramach finansowych wydatki należy wykorzystać do wspierania wzrostu gospodarczego, zatrudnienia, konkurencyjności i konwergencji zgodnie ze strategią „Europa $2020 "$ ".

j) Polityka podatkowa powinna przyczyniać się do konsolidacji fiskalnej i trwałego wzrostu gospodarczego. Należy kontynuować prace i dyskusje nad wnioskami Komisji dotyczącymi opodatkowania energii, wspólnej skonsolidowanej podstawy opodatkowania osób prawnych oraz nad zmianą dyrektywy w sprawie opodatkowania dochodów z oszczędności. Jak odnotowano na posiedzeniu Rady w dniu 22 czerwca 2012 r., nie zostanie przyjęty w rozsądnym terminie wniosek w sprawie podatku od transakcji finansowych. W związku z tym kilka państw członkowskich zgłosi wniosek o wzmocnioną współpracę w tym obszarze, z myślą o jego przyjęciu do grudnia 2012 roku. Komisja nadal prowadzi prace nad konkretnymi metodami sprawniejszego zwalczania oszustw podatkowych i uchylania się od opodatkowania; przedstawi wkrótce plan działania obejmujący możliwe sposoby postępowania w tym zakresie. Należy szybko osiągnąć porozumienie co do wytycznych negocjacyjnych w sprawie porozumień $z$ państwami trzecimi o opodatkowaniu dochodów z oszczędności. Państwa członkowskie uczestniczące w pakcie euro plus będą kontynuowały swoje usystematyzowane dyskusje na temat kwestii polityki podatkowej, zwłaszcza aby zapewnić wymianę najlepszych praktyk.

k) Oczywistym priorytetem jest zwiększanie zatrudnienia, zarówno kobiet, jak i mężczyzn, w szczególności osób młodych i długotrwale bezrobotnych. Rada szybko przeanalizuje wnioski zawarte w komisyjnym pakiecie dotyczącym zatrudnienia - oraz podejmie decyzje w ich sprawie - koncentrując się na tworzeniu miejsc pracy dobrej jakości, strukturalnych reformach rynków pracy oraz inwestycjach w kapitał ludzki. Kluczowe znaczenie ma zajęcie się bezrobociem osób młodych, w szczególności dzięki inicjatywom Komisji w zakresie gwarancji dla młodzieży i ram jakości praktyk zawodowych. Należy także propagować powrót do pracy starszych pracowników. Trzeba usprawnić unijne zarządzanie, w tym wielostronny nadzór nad politykami zatrudnienia.

1) Należy ułatwić mobilność pracowników w obrębie UE. Należy rozwinąć portal EURES, by stał się prawdziwym europejskim narzędziem pośrednictwa pracy i rekrutacji; należy również sprawdzić możliwości rozszerzenia jego zakresu o przyuczanie do zawodu i praktyki zawodowe, jak i możliwość dalszego wspierania działania przygotowawczego „Twoja pierwsza praca z EURES-em”. Należy opracować nowe unijne instrumenty lepszego wyszukiwania potrzebnych nowych umiejętności, poprawić systemy uznawania kwalifikacji zawodowych i umiejętności językowych, zmniejszać liczbę zawodów regulowanych oraz ułatwiać nabywanie i zachowywanie transgranicznych uprawnień emerytalnych $i$ innych praw związanych z zabezpieczeniem społecznym przysługujących pracownikom UE. Należy także posunąć do przodu prace nad wnioskiem w sprawie egzekwowania praw pracowników delegowanych. 
m) Trzeba lepiej wykorzystywać handel jako motor wzrostu gospodarczego. Unia Europejska jest zdecydowana propagować wolny, sprawiedliwy i otwarty handel, broniąc jednocześnie swoich interesów, w duchu wzajemności i obustronnych korzyści, zwłaszcza w stosunkach z największymi gospodarkami świata. Należy szybko przeanalizować wniosek Komisji dotyczący dostępu do rynków zamówień publicznych w państwach trzecich. Choć głównym celem pozostaje wzmocnienie systemu wielostronnego, szczególne znaczenie dla gospodarki mają prowadzone obecnie i ewentualne przyszłe negocjacje dwustronne. W szczególności należy zwiększyć starania na rzecz usuwania barier w handlu, zapewniania lepszego dostępu do rynku, właściwych warunków do inwestowania, ochrony własności intelektualnej i otwierania rynków zamówień publicznych. Sfinalizowane umowy trzeba szybko podpisać $i$ ratyfikować. Umowy o wolnym handlu z Singapurem i Kanadą należy sfinalizować do końca roku; negocjacje z Indiami potrzebują nowego impulsu z obu stron, należy również dalej prowadzić prace nad pogłębieniem stosunków handlowych UE z Japonią. Szefowie państw lub rządów oczekują zaleceń grupy roboczej wysokiego szczebla UE-USA ds. zatrudnienia i wzrostu oraz zobowiązują się dążyć do rozpoczęcia w 2013 roku negocjacji w sprawie kompleksowej transatlantyckiej umowy o handlu i inwestycjach.

n) Wstępnym warunkiem wzrostu gospodarczego jest stabilność finansowa. Sprawozdanie pt. „W kierunku faktycznej unii gospodarczej i walutowej” pokrótce przedstawia ważne kwestie w tym zakresie. Istnieją obszary, w których państwa członkowskie posiadające wspólną walutę - i inne państwa członkowskie, które mają zamiar przyłączyć się do ich wysiłków - chcą pójjść dalej w działaniach na rzecz koordynowania i integrowania swoich polityk finansowych, fiskalnych i gospodarczych w ramach Unii Europejskiej, w pełni respektując integralność jednolitego rynku i Unii Europejskiej jako całości. 